\title{
PLA2G4A wt Allele
}

National Cancer Institute

\section{Source}

National Cancer Institute. PLA2G4A wt Allele. NCI Thesaurus. Code C49365.

Human PLA2G4A wild-type allele is located within $1 \mathrm{q} 25$ and is approximately $160 \mathrm{~kb}$ in length. This allele, which encodes cytosolic phospholipase A2 protein, plays a role in the biosynthesis of prostaglandins, leukotrienes and platelet-activating factor. 